\title{
Effective Behavior of EFL Teachers as Perceived by Undergraduate Students in Indonesia
}

\author{
Mashadi Said ${ }^{1}$ \\ ${ }^{1}$ English Language Center, Azzahra University, Jakarta, Indonesia \\ Correspondence: Mashadi Said, English Language Center, Azzahra University, Jalan Jatinegara Barat 144, \\ Jakarta Timur, Indonesia, 13320. Tel: 6221-2800-647; 62-812-82-30-874. E-mail: mashadisaid77@gmail.com
}

\author{
Received: July 21, 2017 Accepted: September 3, 2017 Online Published: September 5, 2017 \\ doi: 10.5539/elt.v10n9p50 URL: http://doi.org/10.5539/elt.v10n9p50
}

\begin{abstract}
This study attempts to explore the effective behaviors of teachers of English as a foreign language (EFL) as perceived by undergraduate students in Indonesia. For this purpose, a questionnaire was administered to 270 Indonesian undergraduate students. The questionnaire addressed seven dimensions of EFL teachers' behavior, which are the following: encouraging contact between students and teachers; developing reciprocity and cooperation among students; encouraging active learning; giving prompt feedback; emphasizing time on tasks; communicating high expectations; and respecting diversity in talents and ways of learning. Overall, the students perceived that the EFL teachers' behavior that most significantly promotes effective learning is the provision of a learning situation in which students will be optimally engaged in learning. These findings call for the implementation of the seven fundamental principles with their accompanying items for effective teaching and learning in undergraduate education in Indonesia.
\end{abstract}

Keywords: effective EFL learning, effective EFL teacher, effective teacher's behavior, English language teacher

\section{Introduction}

This study addresses the effective behaviors of EFL teachers that positively affect EFL learning. Studying the effective types of EFL teachers' behavior as perceived by undergraduate students in Indonesia is beneficial, especially, for EFL teachers. Such research can help EFL teachers to understand what undergraduate students expect from them so they can practice and develop their pedagogical techniques as well as improve their overall teaching abilities.

Over the past few years, a number of studies have identified the common characteristics of effective EFL teachers in the context of non-English speaking countries. For example, Park and Lee (2006) conducted research into the characteristics of effective EFL teachers in Korea. Overall, the results indicated that the teachers perceived significantly different characteristics from the students. The teachers ranked English proficiency as the highest, while the students ranked pedagogical knowledge the highest.

Chen and Lin (2009) investigated junior high school students' perceptions of the characteristics of effective English teachers. The findings of the study indicated that students generally perceived teachers' personality and the teacher-student relationship to be more important characteristics than those of instructional competence. Another study was conducted by Kourieos and Evripidou (2013) who identified the behavior of university EFL teachers that students considered to be effective. Such behaviors included taking into consideration students' individual differences, language anxiety, abilities and interests and design learning environments. Language teachers' skills in using instructional technology and engaging students in meaningful classroom interactions through group tasks that are designed around real-life topics and authentic language use have also been emphasized. Al-Mahrooqi, Denman, Al-Siyabi and Al-Maamari (2015) conducted research on the characteristics of a good EFL teacher from the Omani EFL teacher and student perspectives. The study sought to compare Omani school students' and teachers' perceptions of the characteristics of good EFL teachers in the Omani context. The results indicated that the Omani students and teachers generally agree about the importance of English language proficiency and treating students equally, and knowledge of Western cultures.

Badshah (2016) researched the qualities of effective EFL teachers from the perspective of Pakistani students and found that effective EFL teachers are those who utilize different strategies to solve the language difficulties of 
mixed-ability students. The students emphasized EFL teachers' strong communicative skills as well as their capacity to help student to improve their communicative competence as the qualities that were considered to be effective.

Liando (2015) conducted one of the very few studies on effective EFL teachers as perceived by undergraduate students in Indonesia. She conducted research on the best EFL teacher characteristics from the perspectives of students and teachers in a university context. The top four characteristics were friendliness, kindness, mastery of subject matter knowledge, and the employment of an engaging teaching delivery. The findings of the previous studies have shown common characteristics of effective EFL teachers, which fall into three categories, specifically subject matter knowledge, pedagogical knowledge, and socio-affective skills. The studies indicated that effective EFL teachers should have the precise characteristics that are needed to achieve successful language teaching. However, the findings did not represent more elaborate and comprehensive types of behavior of EFL teachers, which in turn could provide a focus for EFL teachers' work.

Thus, the present study provides more elaborate types of EFL teachers' behavior. In addition, it addresses the question of effective teaching in undergraduate EFL education from perspective of undergraduate student in Indonesia. The study offers the types of teachers' behavior that will ultimately determine the most effective approach to EFL teaching in undergraduate education.

\subsection{Behavior for Effective EFL Teaching and Learning}

The behavior of EFL teachers that underpins the theory and framework of this study is based on Chickering and Gamson (1987), who offered seven principles of behavior that EFL teachers should put into operation for good teaching and learning in undergraduate education. The behavior was formulated based on 50 years of research on how teachers teach and students learn. The principles were designed as guidelines for EFL teachers, students, and administrators to improve teaching and learning in undergraduate education.

The seven dimensions of behavior for effective teaching and learning practices in undergraduate education include the following: encouraging contact between students and teachers, developing reciprocity and cooperation among students, using active learning techniques, giving prompt feedback, emphasizing time on tasks, communicating high expectations, and respecting diverse talents and ways of learning.

\subsubsection{Encouraging Contact between Students and Teachers}

The first behavior, that is, encouraging contact between students and teachers, means that there should be intensive or frequent contact between students and faculty members in and out of classes. Teachers should adopt a demeanor that communicates that they are approachable and that students are always welcome in the teacher's office. Friendly contact between students and teachers both inside and out of classes will improve the motivation and involvement of the students. In other words, the demonstration of the teachers' concern helps students to get through challenging times and encourages them to continue with their studies (Chickering and Gamson, 1987). Umbach and Wawrzynski (2005) reported that students' higher levels of engagement and learning occur at institutions where there is frequent interaction between students and teachers.

\subsubsection{Developing Reciprocity and Cooperation among Students}

The second behavior is developing reciprocity and cooperation among students. The principle expresses that "good learning, like good work, is collaborative and social, not competitive and isolated. Working with others in which sharing one's own ideas and responding to other's reactions that may occur often increases involvement in learning and sharpens thinking as well as deepen understanding" (Chickering and Gamson, 1987).

This principle is closely related to the type of cooperative learning that has recently been encouraged at all levels of education. Cooperative learning is a structured, systematic instructional technique in which small groups work together to achieve a common goal (Slavin, 1991). Siegel (2005) defined cooperative learning as a learning situation in which two or more students work together to complete a common task. There are other types of cooperative learning strategies that have been proven to be effective in enhancing students' achievement. Among them are Group Investigation (Sharan \& Sharan, 1976), Jigsaw (Aronson, Blaney, Stephin, Sikes, \& Snapp, 1978), Learning Together (Johnson \& Johnson, 1999), Student Teams-Achievement Divisions (Slavin, 1995), Teams-Games-Tournament (Slavin, 1995), and Academic Controversy (Johnson, Johnson, \& Smith, 1996).

\subsubsection{Using Active Learning Techniques}

The third behavior is the use of active learning techniques. The principle behind these techniques is that "Learning is not a spectator sport. Students do not learn much just by sitting in class listening to teachers, memorizing prepackaged assignments, and spitting out answers. They must talk about what they are learning, 
write about it, relate it to experiences, and apply it to their daily lives. They must make what they learn part of themselves" (Chickering \& Gamson, 1987). This principle is closely related to the recently issued guide book on policy for the Indonesian Higher Education Curriculum (2014) in which Student Centered-Learning (SCL) is imposed. SCL means that the student takes part in the learning process while the teacher acts as a facilitator.

This principle is implemented by teachers' using a wide variety of teaching methods in which the focus of instruction is the students. The methods that are used are designed to encourage students to actively participate in the teaching-learning process. These include Small Group Discussion, Simulation/Demonstration, Discovery Learning, Self-Directed Learning, Cooperative Learning, Collaborative Learning, Contextual Instruction, Project-Based Learning, Problem-Based Learning/Inquiry (Kementerian Pendidikan dan Kebudayaan Rebuplik Indonesia (Ministry of Education and Culture of Indonesia, 2014).

\subsubsection{Giving Prompt Feedback}

Feedback is an essential part of EFL learning and teaching (Bitchener, 2008). Feedback in this context refers to providing learners with information on their performance. Clarifying what students know and do not know focuses learning. At the beginning of a course, teachers should help the students to assess their existing knowledge and competence. The teacher should follow up by giving a pre-test at the start of the course to assess students' background knowledge in the subject. This approach helps both teachers and students to meet the goals in learning and teaching. During the course, the students need sufficient feedback to see their progress. In addition, students need frequent opportunities to perform and receive suggestions for improvement as well as immediate feedback. For example, feedback on correct or incorrect pronunciation, sentence structure, and word use should be given immediately. However, students need appropriate feedback on performance to benefit from their courses. For example, providing a detailed evaluation of the students' written work and giving corrections that do not embarrass the students, but rather motivates them to achieve their learning goals (Almuhimedi \& Alshumaimeri, 2015). Indeed, teachers should provide sufficient feedback and facilitate students' reflection on what they have learned, what they still need to practice, and how to assess their own progress.

\subsubsection{Emphasizing Time on Tasks}

Time on tasks refers to the length of time that is spent by the students spend active involvement in a task. This concept was introduced by John Carroll's 1963 paper, "A Model of School Learning." He stated that true learning depends on the amount of time that a student actively spends being engaged in the learning process. The finding of the California Beginning Teacher Evaluation Study (BTES) demonstrated that "the more engaged time students have, the higher they achieve. Highly effective teachers use interactive presentations with modeling, questions and answers, guided practice, and constructive feedback before students work independently. It is also interesting to note that high students' engagement during teacher-led instruction and group work yielded high engagement during independent seatwork" (Hankebo, Demissie, Kebede, \& G/Egziabiher, 2015). In this respect, the teacher should allocate the appropriate amount of time to complete assignments promptly, estimate and communicate the amount of time to be spent on tasks, encourage the rehearsal of oral presentations, and encourage steady work and sensible time management.

\subsubsection{Communicating High Expectations}

This principle focuses the importance of the communication of high expectations as early as possible and throughout the course as it is believed to enhance students' learning. Students should be given the consistent message that they are expected to achieve high standards in their school work. The teacher should demonstrate confidence in the students' ability to achieve the learning outcomes that the teacher has set forth. Furthermore, teachers who encourage students to have "high, challenging, and appropriate expectations are among the most powerful influence in enhancing student achievement" (Hattie, 2012).

Teachers should provide opportunities for students to predict their own performance by presenting clear learning goals and success criteria. In addition, it is important to set expectations in the syllabus and objectives in the assignment. It is also necessary to develop interpersonal communication between teachers and students during office hours. High student expectations can also be cultivated through encouragement, positivity, and sensitivity to student needs. Hence, teachers should communicate clear expectations of what they expect students to know and be able to do, communicate the importance of achieving high academic standards, and offer praise when standards are met.

\subsubsection{Respecting Diverse Talents and Ways of Learning}

The importance of taking into consideration in teaching and learning students' talents or aptitudes and the ways in which students learn was cited by Jakobovits (1970) who suggested that there are two affective factors that 
influence students' success in foreign language learning, specifically motivation and aptitude. He further demonstrated that the percentages of the influential factors are as follows: motivation and perseverance $33 \%$, aptitude $33 \%$, intelligence $20 \%$, and other factors $14 \%$. This implies that EFL teachers should address these determining factors.

Another point is that EFL teachers should respect students' styles of learning. Rebecca and Oxford (2003) stated that students are likely to perform well, feel confident, and experience low anxiety if there is harmony between the students' learning style and strategy preferences and the combination of instructional methodology and materials that is employed. Scarcella and Oxford (1992) stated that the term "learning styles" refers to "the general approaches-for example, global or analytic, auditory or visual-that students use in acquiring a new language or in learning any other subject."

\section{Methods}

\subsection{Participants}

Several classes of undergraduate students $(\mathrm{N}=270)$ at two private universities in Jakarta were asked to complete questionnaires about the most effective EFL teachers' behaviors. The students had studied English as a foreign language for six years in secondary schools (three years in junior high school and three years in senior high school).

\subsection{Development of the Questionnaire}

The questionnaire for this study was designed based on Chickering and Gamson (1987): Seven Principles of Good Teaching and Learning Practices in undergraduate education. Items within the seven dimensions were specifically worded to reflect the intent of the question within the context of EFL teaching and learning principles. The student responses were elicited using a six-point Likert-type scale that ranged from strongly agree to strongly disagree. The items within each dimension were specially formulated to reflect the intent of the question within the context of EFL learning. Thirty-four items were developed under seven dimensions: encouraging contact between students and faculty (three items); developing reciprocity and cooperation among students (four items); using active learning techniques (seven items); giving prompt feedback (five items); emphasizing time on task (four items); communicating high expectations (seven items); and respecting diversity in talents and ways of learning (four items).

The content validity of the questionnaire was reviewed by a panel of faculty members that consisted of one professor who specializes in TEFL and one expert who specializes in the research and evaluation of education. Items were reviewed for clarity, accuracy, and relevance for the assessment of the EFL teacher behaviors that promote effective learning. In the next stage, the items were tested on 135 undergraduate student respondents outside of the participants of the study. The test results indicated that the 34-item questionnaire was highly reliable, and it yielded an internal consistency of .93 .

\subsection{Data Collection and Analysis}

The data with regard to the EFL teachers' behavior as perceived by the students were collected with the cooperation of the faculty members who were in charge of the classes. The students attended two private universities. The researcher briefly explained the nature of the study and asked for the students' cooperation by responding to the questionnaires sincerely and honestly. The students were assured that their responses to the questionnaires would be kept confidential and not be used for other purposes. Moreover, they were assured that their contributions would be useful and beneficial for the development of EFL teaching and learning in Indonesia. In addition, they were told that there were no correct or incorrect answers to the questionnaires. The researcher encouraged the students to ask questions if the meanings of the items were not clear to them. The questionnaires were in Indonesian to avoid any possible bias that resulted from their understanding of English.

To support the questionnaire, the researcher interviewed the students with regard to the behavior of EFL teachers who promote effective learning. The interviews aimed to obtain more detailed information in addition to the data that were obtained from the questionnaire. However, more importantly, the interview was designed to obtain more and deeper information with regard to the objective of the study.

To elicit the behavior of EFL teachers that is perceived by the students to most significantly promote positive effects on learning English, the representations of a multilevel logic form was employed in the analysis. The representation was divided into three levels, i.e., Level One (Strongly Agree and Agree), Level Two (Mildly Agree, Mildly Disagree), and Level Three (Disagree, and Strongly Disagree). Employing this logic form, Level One (Strongly Agree and Agree) was considered to be convincing in the respondents' responses and indicated that they were in agreement with the teachers' behavior. To determine the perception of the respondents, first the 
researcher compared all of the dimensions to determine the dimension(s) that received the most favorable responses; and second, the researcher analyzed the items within the dimensions to determine the most favorable item(s) within the dimensions. The responses were then discussed with the support of the interview results.

\section{Findings and Discussion}

The findings of this study are considered with a focus on the effective behavior of EFL teachers in promoting positive effects on EFL learning - the favorable behavior within the seven dimensions that students think would motivate or encourage them to more effectively learn EFL. They are presented in two categories, specifically between dimensions and within dimensions. The responses of the students are enriched with the support of the interview results.

It should be noted here that any conclusions that are taken from these findings should be interpreted with caution because the data were collected at one point in time in two private universities in Indonesia. A large number of students from approximately 3320 public and private universities throughout Indonesia were not involved in the study. However, the findings can be transferable to other university settings according to the nature of the study and the EFL setting.

\subsection{Between Dimensions}

The seven dimensions have been identified as the principles for good practice in undergraduate education. Those dimensions with their accompanying items indicate teachers' behavior, which is shown in Figure 1, are the representation of Strongly Agree and Agree (SAA) of the students' responses.

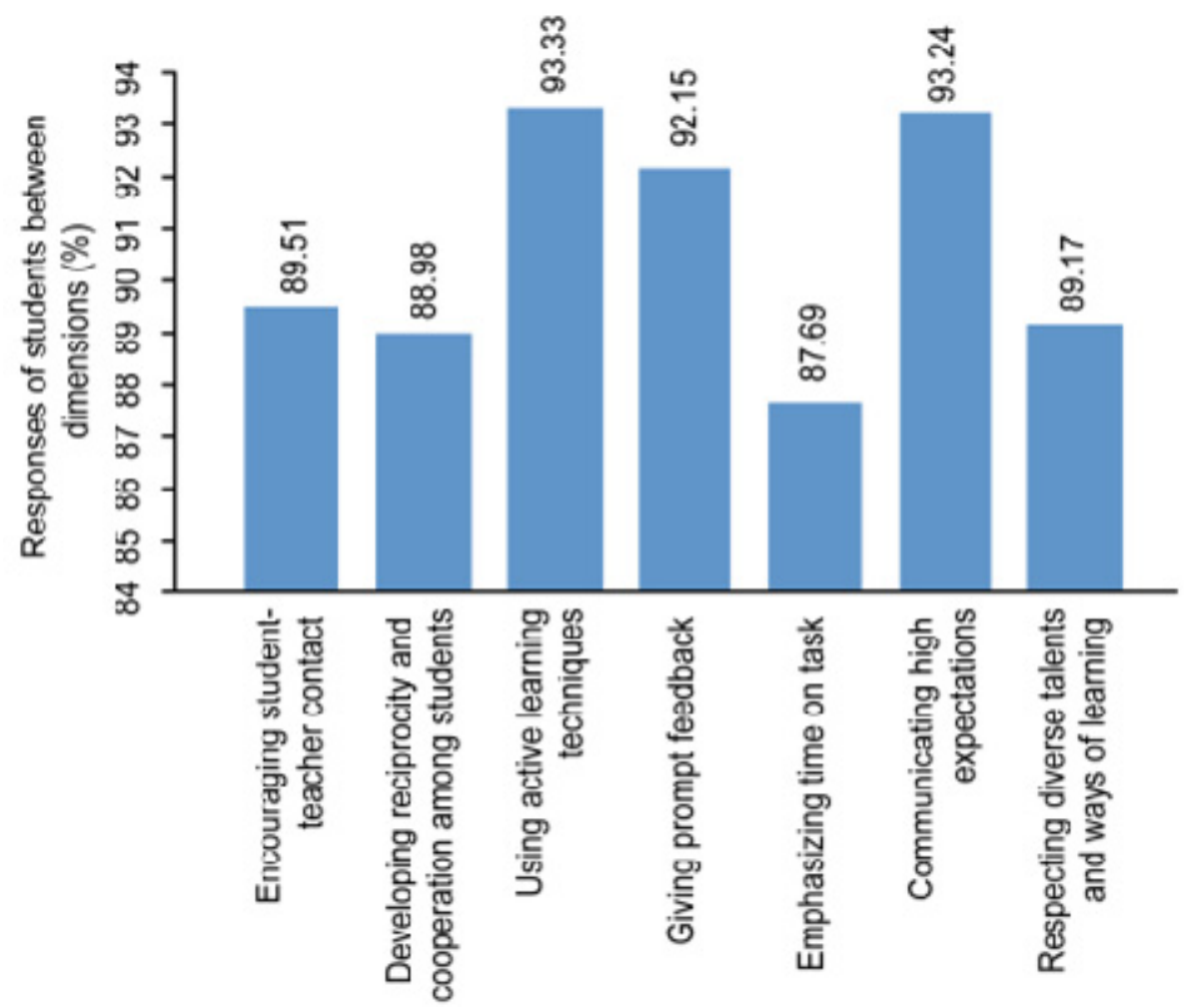

Figure 1. Responses of students between dimensions

The majority of the students perceived that the seven dimensions are important types of EFL teachers' behavior that promote effective EFL learning. Most of the students believed that "encouraging contact between students and teachers" (89,51\%), "developing reciprocity and cooperation among students" (88,98\%), "using active learning" (93,33\%), "giving prompt feedback" (92,15\%), "emphasizing time on task" (87,69\%), "communicating high expectations" (93,24\%), "respecting diversity in talents and ways of learning" $(89,17 \%)$ were important types of behavior that EFL teachers in Indonesia should practice for undergraduate EFL education. This implies that the findings call for the implementation of the seven dimensions in EFL learning. 
In addition, the diagram shows that there are three dimensions that received higher responses (more than 90\%) from the students, i.e., "using active learning," "communicating high expectations," and "giving prompt feedback." The first indicates that the most effective type of behavior of EFL teachers that should be implemented is Student-Centered Learning (SCL). It broadly encompasses methods of teaching that shift the focus of instruction from the teacher to the student. The method, which encourages students to actively participate in the teaching-learning process, includes discovery learning, cooperative learning, self-directed learning, project-based learning, simulation and/or demonstration, presenting work to the class, asking students to relate outside events to class material, giving students real-life situations to analyze, and role-playing.

The finding confirmed the previous findings that an effective teacher should encourage active student participation, i.e., involving students in the teaching-learning process (Witcher \& Onwuegbuzie, 1999). Further, Kourieos and Evripidou. op.cit. found that effective EFL teacher behavior is not directive and authoritative, but rather it involves taking into consideration students' individual differences, anxieties, abilities, interests and creating active learning environments.

The second most favorable dimension is "communicating high expectations," which indicates that clear EFL learning goals must be set. The teacher should remind the students early on that their goal of learning is to be proficient in English, both orally and written. Hence, the goal might be graded from elementary up to advanced levels. Examples of such goals include correctly pronouncing English sounds and English words, mastery of a certain number of English words (one thousand, two thousand, and three thousand word lists by nation), and knowledge of English sentence patterns. Another goal might be being able to understand authentic English texts in any context or to use English in any settings. Indeed, clear learning goals are essential so that the students will know their target. In fact, setting learning goals is believed to increase motivation and achievement (Bryan \& Locke, 1967; Locke \& Latham, 2002).

The third dimension, "giving prompt feedback" is another dimension of behavior that EFL students in Indonesia perceived to be an important teaching practice that promotes effective EFL learning. The behavior refers to the process of helping students to assess their performance, identifying areas where they are succeeding and providing them with ways in which they can improve in areas that require correction.

Although the other dimensions did not receive as high responses as the three above-described dimensions, they cannot be ignored by EFL teachers in the learning and teaching process. Chickering and Gamson (1987) stated, "While each practice can stand on its own, when they are all present, their effects multiply. Together, they employ six powerful forces in education: Activity, Cooperation, Diversity, Expectations, Interaction, and Responsibility."

\subsection{Within Dimensions}

The within-dimensions findings and discussion are presented according to the original order of the seven dimensions, which include the following: encouraging contact between students and teachers, developing reciprocity and cooperation among students, using active learning techniques, giving prompt feedback, emphasizing time on tasks, communicating high expectations, and respecting diverse talents and ways of learning.

\subsubsection{Within Dimension 1: Encouraging Contact Between Students and Teachers}

The responses of the respondents for the items within the dimension of "encourage student-teacher contact" were calculated to determine the relative importance of the items as they were perceived by the students. The three teachers' behavior items received positive responses from the students as is displayed in the Appendix: "adopt a demeanor that communicates that the teachers are approachable" (93,96\%), "welcome students to drop by the teachers" office to discuss academic matters" $(86,30 \%)$, and "welcome students to communicate by telephone, e-mail, and other types of electronic media" $(89,26 \%)$.

Most students want their teachers to be friendly, have a love of students, and create the possibility for the students to interact with the teachers inside and outside of the classroom. Most of the students commented, "We want all of the teachers to be friendly to all of the students, both inside and outside the classroom and to be available outside of school hours. In the current information technology era, we hope that all teachers can be contacted by electronic media such as mobile phone, e-mail, SMS, WA, BB, etc." Other students commented that some [some teachers] are very helpful and are willing to meet any time on campus. This personalized interaction motivates us to learn actively and solve the learning problems I encountered." Indeed, Chickering and Gamson (1987) summarized, "knowing a few faculty members well enhances students' intellectual commitment and encourages them to think about their own values and future plans." 


\subsubsection{Within Dimension 2: Developing Reciprocity and Cooperation among Students}

With regard to "developing reciprocity and cooperation among students" the four items in this dimension received high responses from the students as is displayed in the Appendix: "encourage the students to interact with one another in the classroom" (91,11\%), "group the students into jigsaw and other types of group discussion" (84,81\%), "employ think/pair/share technique" (96,67\%), and "create project team for an assignment outside the classroom" (83,33\%).

This suggests that students like to interact and share with one another in group discussions. For example, "grouping the students into a jigsaw group and other types of group discussion" received a positive response from the students. Some of the students claimed, "We like to be in the jigsaw group discussion because it allows us to actively interact with the members of the group." As introduced by Aronson et al. op.cit. that jigsaw is an effective and efficient way for students to be engaged in learning, to learn extensive material quickly, to share information with other groups, to minimize listening time and to be individually accountable for their own learning. This claim is confirmed in the study of Mengduo and Xiaoling (2010) who found that 'jigsaw technique is an effective way to promote student participation and enthusiasm as well as a useful technique for language learners to accomplish learning tasks in the EFL classroom."

Although the item "create project team for an assignment outside the classroom" appears to receive a positive response from the students, there is a meaningful claim from the students to which the teachers should pay attention. Most students do not like large study groups. They indicate that they do not find such groups to be effective because there are members who do not participate well in it. Some students commented, "Well, usually there are some group members who are lazy [not active] about participating in the group; not all members of the group take part in it, so we prefer to have a small one, for example, one that consists of three or four members, four members at the most." In addition, the students commented, "We find it difficult to have discussions outside of the classroom as we always encounter problems of time, place of discussion, and traffic." The students' endorsement to keep group discussions small in the classroom suggests that for group discussions to be effective, groups should be kept small (Slavin, 2011) because it allows group members to interact more frequently and intensively and because the number of participants limits the amount of information that is used in arriving at a decision ( Johnson, Johnson, \& Stanne, 2000). A small group also increases individual responsibility (Johnson, 2009).

\subsubsection{Within Dimension 3: Using Active Learning Techniques}

All of the items within this dimension of behavior received positive responses from the students as is displayed in the Appendix: "use diverse teaching activities that encourage the students to practice their English actively" $(100 \%)$, "guide the students to learn autonomously — to make the students aware of taking charge of their own learning" (91,11\%), "use simulations and role-play in the classroom" $(95,19 \%)$, "employ problem solving techniques" $(94,44)$, "incorporate real-life situations into instruction" $(96,30 \%)$, "employ discovery learning technique" $(90,74)$, "ask students to present work to the class" $(85,56 \%)$.

The students perceive that active learning techniques are necessary for them to obtain optimal engagement in learning English as a foreign language. The students require a great deal of practice to become proficient in English. The teachers should relinquish the old-fashion method-teacher centered learning-in which the teachers are dominant in the teaching-learning process. Some students commented, "We like when our teachers provide us with activities in which we can have more chances to practice our English as we do not have many opportunities to use it outside the classroom. In addition, we want our teachers to provide us with a lot oral and written exercises which lead us to have good command of English." Other students said, "We want our teachers to guide us how to be independent leaners, so that we can improve our English ourselves." The students expressed their approval of the 2014 curriculum for higher education in Indonesia, which suggests more effective teaching methods, specifically student-centered learning (SCL) methods. Active learning is supported by Lengkanawati's (2017) finding that "learner autonomy-based teaching-learning practices are most desired although they need commitment from the teacher and the students."

\subsubsection{Within Dimension 4: Giving Prompt Feedback}

All of the items in dimension four, "giving prompt feedback" received high responses from the students as is displayed in the Appendix: "give a pre-test at the beginning of the course to assess students' background in the subject" (95,56\%), "provide classroom activities that give immediate feedback" (93,33\%), "provide sufficient opportunities for assessment" $(82,86)$, "discusses the progress of students" $(91,48)$, "return graded assignments in a timely manner" $(97,41)$. 
Overall, the students perceived that "giving prompt feedback" is important to increase their motivation in learning. One student noted, "I want my teacher to provide me with a presentation exercise in which I can speak in English and then the teacher corrects my mistakes immediately. I want the teacher to show me what I have and have not done correctly, so that I will not repeat the same mistakes."

However, some students claimed that only a very few teachers returned their homework, while the students wanted to obtain a sense of their own progress. Some students commented, "We want our teachers to look into our work and tell us what we can and cannot do." In addition, the students want their teachers to correct their mistakes promptly in the classroom. One student stated, "I want my teacher to correct my mistakes right after my presentation exercise." "I want my teacher to show me the mistakes and show me how I can express it in a correct and appropriate way." Overall, the students expressed that teachers should provide sufficient feedback, specifically they should facilitate students' capacity to reflect on what they already know and what they should learn next.

\subsubsection{Within Dimension 5: Emphasizing Time on Tasks}

With regard to "emphasizing time on tasks," specifically promoting student engagement in learning, all of the items in the dimension received positive responses from the students: "the teacher starts the class with puzzles to be solved, or the teacher presents a mystery to be understood" $(88,15 \%)$, "estimate and communicate the amount of time to be spent on tasks" $(88,15 \%)$, "encourage rehearsal of oral presentations" $(85,19 \%)$, and "teacher sets consequences for non-completion of work" $(87,69 \%)$.

The majority of the participants commented in the interview that the strategy of starting the class with puzzles triggers their attention and focus. Some students commented, "Questions from the teacher that should be answered increase my focus on the lesson. We usually get bored and lose our focus if the teacher talks too much." In addition, determining the amount of time to complete assignments both inside and outside of the classroom increases the students' motivation to complete a task in a timely manner. Some students noted, "We will be motivated to learn if the teacher determines the amount of time to do the task both in and outside of the classroom. Setting a high time on tasks makes everybody busy with the tasks."

In line with "giving oral presentation," most students said that oral presentation increases their attention and improves their focus on the material. A student said, "Sometimes I cannot sleep thinking of the oral presentation assignment, so that I have to stay up late at night to prepare myself until I feel more comfortable with my preparation."

One important claim from the students is a reminder to the teacher to set consequences for the students who do not complete their homework. A student noted, "I do not like when the teachers give me a lot of homework because some teachers do not check them whether we have done them correctly or not. Moreover, students who do not complete the home work are not given punishment." This implies that engaging the students with a lesson that has been learned should not involve overwhelming homework assignments or tasks, and there must be a reasonable amount of time for students to complete assignments.

\subsubsection{Within Dimension 6: Communicating High Expectations}

The results from the items that were written to assess "communicating high expectations" indicate that most of the items in the dimension received positive responses from the students: "set challenging goals for all courses" $(84,81 \%)$, "providing examples of excellent use of English that clearly communicate future goals of learning English" (98,15\%), "motivate students to have good command of English both written and oral" (97,78\%), "setting activities that require familiarity with grammar points, vocabulary words, pronunciation, and cultural competency" (92,22\%), "motivate the students to achieve a certain level of English proficiency—equivalent to a 550 TOEFL score" (86,30\%), and "provide authentic use of English expected to be achieved by the students, e.g., national English newspapers or English TV news (93,33\%).

It is clear from the students' responses that setting challenging goals for all courses motivate them to learn. One student noted, "One thing I find motivating is that when the teacher sets a challenging goal for the course." In addition, some students mentioned, "We want the teachers to tell us the objectives of the courses clearly at the beginning of the class, so that we will prepare ourselves with any consequences to undergo the courses." This implies the necessity of setting up expectations in the syllabus and objectives of the course material.

Another item that became a focus of the students was "providing examples of excellent use of English that clearly communicate future goals of learning English." Some students said, "We want our teachers to show us examples of using English correctly and appropriately. We sometimes notice that not all EFL teachers have a good command of English." In this regard, the teacher may not be proficient in English should be creative in 
finding ready-made materials or video tape to cater to the student needs for authentic input with correct and appropriate use of English. Some students commented, "We are really motivated when the teacher uses authentic materials in teaching." This implies the necessity of using authentic materials in teaching English as a foreign language.

The next item the students gave their attention is "setting activities that require familiarity with grammar points, vocabulary words, pronunciation, and cultural competencies." Most of the students wanted their teachers to provide materials and activities to help them to become familiar with grammar points, vocabulary words, pronunciation, and cultural background - using English correctly and appropriately. Some students said, "We find ourselves with little choice of words to use, wrong pronunciation, and bad grammar. We are not confident enough to speak or write in English."

One item that received a lower percentage from the students was "bring the students to a workplace environment where a high level of English proficiency is required" $(62,96 \%)$. Some students commented, "Going to a workplace where English is used is time consuming and expensive. This context can be represented the use of authentic materials in various contexts." The results suggest that the use of authentic materials as a model of using English triggers the students to achieve high level of English proficiency. This clearly not only communicates high expectations, but it also provides students with challenging goals to achieve. Extra effort should be made by teachers and institutions to facilitate students' in meeting their EFL learning goals. Chickering and Gamson (1987) noted that "expecting students to perform well becomes a self-fulfilling prophecy when teachers and institutions hold high expectations of themselves and make extra efforts."

\subsubsection{Within Dimension 7: Respecting Diverse Talents and Ways of Learning}

All of the items within Dimension Seven, specifically "respecting diverse talents and ways of learning" received positive responses from the students as is displayed in the Appendix: "Respect students' diverse talents and ways of learning" (91,48\%), "cater to students' learning styles" (82,96\%), "cater to students' needs" $(94,44 \%)$, "provide students with various ways to explain important concepts" (87,78\%). This implies the necessity of taking into account the range of students' talents and ways of learning. Some students may be visual leaners, while others are auditory and kinesthetic. Some students mentioned, "We really appreciate the teacher who provides us with different kinds of learning activities, for example, listening and watching native speakers through video-tape and multimedia." Other students said, "I enjoy being involved in the activities in which I can demonstrate my English, for example, drama." The students suggest that the teacher should cater to the students' learning preferences. Another point that the students take into consideration is the background of the students. Students usually come from different backgrounds - family, ethnic group, and economic. A teacher should not be biased towards the students, and the teacher should be fair and treat the students equally. Some students commented, "We like the teacher who treats us fairly and indiscriminately." Indeed, Chickering and Gamson (1987) noted, "students need the opportunity to show their talents and learn in ways that work for them."

\section{Conclusions and Suggestions}

Using a questionnaire and interviews, this study investigated the types of effective behavior of EFL teachers that promote positive effects on EFL learning as perceived by undergraduate students in Indonesia. Overall, the seven dimensions of EFL teachers' behavior are the perceived significant types of behavior that could promote effective EFL learning in undergraduate education. Three dimensions received very positive responses by more than $92 \%$ of the respondents, i.e., "using active learning techniques," "giving prompt feedback," and communicating high expectations." Four others (encouraging student-teacher contact, developing reciprocity and cooperation among students, emphasizing time on tasks, and respecting diverse talents and ways of learning) received positive responses by more than $87 \%$ of the respondents. The results suggest the necessity of implementing all of the dimensions to achieve optimum EFL learning results in undergraduate education.

Interestingly, nineteen out of thirty-four items of teachers' behavior within the seven dimensions received a high percentage of students responses ( $>90 \%)$. Fourteen items received a percentage of more than $87 \%$, and only one item received $63 \%$ from the students. This means that the items of teachers' behavior that are suggested in the dimensions are perceived to be significant in promoting effective EFL learning. In other words, most of the students perceived that all of the items with regard to effective types EFL teachers' behavior are essential to promote effective EFL learning in undergraduate education.

Two limitations are inherent in the present study. The data for the study were taken from two private universities in Indonesia, which were not entirely representative of university students throughout Indonesia. Future research can be conducted to investigate more students from different parts or provinces in Indonesia to check whether other university students hold the same beliefs about EFL teachers' types of behavior that bring about effective 
EFL learning. The second limitation is that the data collection was performed at one time, so that the result of the study might be different in future conditions. Thus, similar studies should be conducted in the future.

\section{References}

Al-Mahrooqi, R., Denman, C., Al-Siyabi, J., \& Al-Maamari, F. (2015). Characteristics of a good EFL teacher. SAGE Open, 5(2), 1-15. https://doi.org/10.1177/2158244015584782

Almuhimedi, R. A., \& Alshumaimeri, Y. A. (2015). Effective error correction in grammar classes: A students' perspective. American International Journal of Contemporary Research, 5(6).

Aronson, E., Blaney, N., Stephin, C., Sikes, J., \& Snapp, M. (1978). The jigsaw classroom. Beverly Hills, CA: SAGE Publications.

Badshah, I. U. Y. (2016). Different qualities of effective EFL teachers (Unpublished doctoral dissertation). The British University in Dubai, Dubai.

Bitchener, J. (2008). Evidence in support of written corrective feedback. Journal of Second Language Writing, 17(2), 102-118. http://dx.doi.org/10.1016/j.jslw.2007.11.004

Bryan, J. F., \& Locke, E. A. (1967). Goal setting as a means of increasing motivation. The Journal of Applied Psychology, 51(3), 274-277. https://doi.org/10.1037/h0024566

Chen, Y., \& Lin, S. (2009). Exploring characteristics for effective EFL teachers from the perceptions of junior high school students in Tainan. STUT Journal of Humanities and Social Sciences, 2, 219-249.

Chickering, A. W., \& Gamson, Z. F. (1987). Seven principles for good practice in undergraduate education. AAHE Bulletin, 3, 3-7.

Hankebo, D. D., Demissie, E. B., Kebede, D. D., \& G/Egziabiher, M. (2015). Students time utilization practices in school and home environments in the primary schools of Boloso Sore Woreda, Wolaita Zone Southern Ethiopia. Global Journal of Human-Social Science Research: Linguistic \& Education, 15(6).

Hattie, J. (2012). Visible learning for teachers: Maximizing impact on learning. New York: Taylor \& Francis.

Jakobovits, L. A. (1970). Foreign language learning: A psycholinguistic analysis of the issues (2nd ed). Rowley, MA: Newbury House.

Johnson, D. W. (2009). Reaching out: Interpersonal effectiveness and self-actualization (10th ed). Boston: Allyn $\&$ Bacon.

Johnson, D. W., \& Johnson, R. T. (1999). Making cooperative learning work. Theory into Practice, 38(2), 67-73. https://doi.org/10.1080/00405849909543834

Johnson, D. W., Johnson, R. T., \& Smith, K. A. (1996). Academic controversy. Enriching college instruction through intellectual conflict. ASHE-ERIC higher education report, Vol. 25, No. 3. Washington, DC: Graduate School of Education and Human Development, George Washington University.

Johnson, D. W., Johnson, R. T., \& Stanne, M. B. (2000). Cooperative learning methods: A meta-analysis. Journal of Research in Education, 12(1), 5-14.

Kementerian Pendidikan dan Kebudayaan Rebuplik Indonesia (Ministry of Education and Culture of Indonesia). (2014). Buku Kurikulum Pendidikan Tinggi. Direktorat pembelajaran dan kemahasiswaan direktorat jenderal pendidikan tinggi

Kourieos, S., \& Evripidou, D. (2013). Students' perceptions of effective EFL teachers in university settings in Cyprus. English Language Teaching, 6(11), 1. https://doi.org/10.5539/elt.v6n11p1

Lengkanawati, N. S. (2017). Learner autonomy in the Indonesian EFL settings. Indonesian Journal of Applied Linguistics, 6(2), 222-231. https://doi.org/10.17509/ijal.v6i2.4847

Liando, N. V. (2015). Students' vs. teachers' perspectives on best teacher characteristics in EFL classrooms. TEFLIN Journal: A Publication on the Teaching and Learning of English, 21(2), 118-136.

Locke, E. A., \& Latham, G. P. (2002). Building a practically useful theory of goal setting and task motivation. A 35-year odyssey. The American Psychologist, 57(9), 705-717. https://doi.org/10.1037/0003-066X.57.9.705

Mengduo, Q., \& Xiaoling, J. (2010). Jigsaw strategy as a cooperative learning technique: Focusing on the language learners. Chinese Journal of Applied Linguistics, 33(4).

Oxford, R. L. (2003). Language learning styles and strategies: An overview. Proceedings of GALA (Generative Approaches to Language Acquisition) Conference (pp. 1-25). Oxford: Learning Styles \& Strategies. 
Park, G.-P., \& Lee, H.-W. (2006). The characteristics of effective english teachers as perceived by high school teachers and students in Korea. Asia Pacific Education Review, 7(2), 236-248. https://doi.org/10.1007/bf03031547

Scarcella, R. C., \& Oxford, R. L. (1992). The tapestry of language learning: The individual in the communicative classroom. Boston: Heinle \& Heinle.

Sharan, S., \& Sharan, Y. (1976). Small-group teaching. Englewood Cliffs, NJ: Educational Technology Publications.

Siegel, C. (2005). Implementing a research-based model of cooperative learning. The Journal of Educational Research, 98(6), 339-349. https://doi.org/10.3200/JOER.98.6.339-349

Slavin, R., E. (2011). Instruction based on cooperative learning. In R. E. Mayer \& P. A. Alexander (Eds.), Handbook of research on learning and instruction (pp. 344-360). New York: Routledge.

Slavin, R. E. (1995). Cooperative learning: Theory, research, and practice. Needham Heights, MA: Allyn and Bacon.

Umbach, P. D., \& Wawrzynski, M. R. (2005). Faculty do matter: The role of college faculty in student learning and engagement. Research in Higher Education, 46(2), 153-184. https://doi.org/10.1007/s11162-004-1598-1

Witcher, A., \& Onwuegbuzie, A. J. (1999). Characteristics of effective teachers: Perceptions of preservice teachers. (ERIC No. ED438246).

\section{Appendix}

\section{Frequency of student responses}

Within Dimension 1: Encourage Student-Teacher Contact

\begin{tabular}{|c|l|c|c|c|c|c|c|c|}
\hline Item & \multicolumn{1}{|c|}{ Item description } & SA & A & MA & MD & D & SD & SAA \\
\hline 1 & $\begin{array}{l}\text { Adopt a demeanor communicating that } \\
\text { teachers are approachable. }\end{array}$ & 72,96 & 20,00 & 7,04 & 0,00 & 0,00 & 0,00 & 92,96 \\
\hline 2 & $\begin{array}{l}\text { Encourage the students to consult on } \\
\text { academic matters with teachers. }\end{array}$ & 39,63 & 46,67 & 9,63 & 4,07 & 0,00 & 0,00 & 86,30 \\
\hline 3 & $\begin{array}{l}\text { Welcome students to communicate by } \\
\text { telephone, e-mail, and other types of } \\
\text { electronic media. }\end{array}$ & 44,81 & 44,44 & 8,89 & 1,85 & 0,00 & 0,00 & 89,26 \\
\hline \multicolumn{2}{c}{ Average } & 52,47 & 37,04 & 8,52 & 1,98 & 0,00 & 0,00 & 89,51 \\
\hline
\end{tabular}

Within Dimension 2: Developing Reciprocity and Cooperation Among Students

\begin{tabular}{|c|l|c|c|c|c|c|c|c|}
\hline Item & \multicolumn{1}{|c|}{ Item description } & SA & A & MA & MD & D & SD & SAA \\
\hline 4 & $\begin{array}{l}\text { Encourage the students to interact with } \\
\text { one another in the classroom. }\end{array}$ & 46,67 & 44,44 & 7,78 & 1,11 & 0,00 & 0,00 & 91,11 \\
\hline 5 & $\begin{array}{l}\text { Group the students into jigsaw and other } \\
\text { types of group discussion. }\end{array}$ & 44,44 & 40,37 & 10,74 & 3,33 & 1,11 & 0,00 & 84,81 \\
\hline 6 & Employ think/pair/share technique. & 67,78 & 28,89 & 3,33 & 0,00 & 0,00 & 0,00 & 96,67 \\
\hline 7 & $\begin{array}{l}\text { Create project team for an assignment } \\
\text { outside the classroom. }\end{array}$ & 39,63 & 43,70 & 11,85 & 4,81 & 0,00 & 0,00 & 83,33 \\
\hline \multicolumn{2}{c}{ Average } & 49,63 & 39,35 & 8,43 & 2,31 & 0,28 & 0,00 & 88,98 \\
\hline
\end{tabular}

Within Dimension 3: Using Active Learning Techniques 


\begin{tabular}{|c|c|c|c|c|c|c|c|c|}
\hline Item & Item description & SA & $\overline{\mathbf{A}}$ & MA & MD & $\overline{\mathbf{D}}$ & SD & SAA \\
\hline 8 & $\begin{array}{l}\text { Use diverse teaching activities that } \\
\text { encourage the students to practice their } \\
\text { English actively. }\end{array}$ & 97,78 & 2,22 & 0,00 & 0,00 & 0,00 & 0,00 & 100,00 \\
\hline 9 & $\begin{array}{l}\text { Guide the students to learn } \\
\text { autonomously-to make the students } \\
\text { aware of taking charge of their own } \\
\text { learning. }\end{array}$ & 78,15 & 12,96 & 7,41 & 1,48 & 0,00 & 0,00 & 91,11 \\
\hline 10 & $\begin{array}{l}\text { Use simulations and role-play in the } \\
\text { classroom. }\end{array}$ & 87,04 & 8,15 & 4,81 & 0,00 & 0,00 & 0,00 & 95,19 \\
\hline 11 & Employ problem solving techniques. & 85,56 & 8,89 & 5,56 & 0,00 & 0,00 & 0,00 & 94,44 \\
\hline 12 & $\begin{array}{l}\text { Incorporate real-life situations into } \\
\text { instruction. }\end{array}$ & 88,89 & 7,41 & 3,70 & 0,00 & 0,00 & 0,00 & 96,30 \\
\hline 13 & Employ discovery learning techniques. & 72,96 & 17,78 & 8,15 & 1,11 & 0,00 & 0,00 & 90,74 \\
\hline 14 & $\begin{array}{l}\text { Ask students to present work to the } \\
\text { class. }\end{array}$ & 38,52 & 47,04 & 9,26 & 1,85 & 1,85 & 1,48 & 85,56 \\
\hline & Average & 78,41 & 14,92 & 5,56 & 0,63 & 0,26 & 0,21 & 93,33 \\
\hline
\end{tabular}

Within Dimension 4: Giving Prompt Feedback

\begin{tabular}{|c|c|c|c|c|c|c|c|c|}
\hline Item & Item description & $\mathbf{S A}$ & $\bar{A}$ & MA & MD & $\overline{\mathbf{D}}$ & SD & $\overline{\text { SAA }}$ \\
\hline 15 & $\begin{array}{l}\text { Give a pre-test at the beginning of the } \\
\text { course to assess students' background in } \\
\text { the subject. }\end{array}$ & 82,59 & 12,96 & 4,44 & 0,00 & 0,00 & 0,00 & 95,56 \\
\hline 16 & $\begin{array}{l}\text { Provide classroom activities that give } \\
\text { immediate feedback. }\end{array}$ & 74,44 & 18,89 & 6,67 & 0,00 & 0,00 & 0,00 & 93,33 \\
\hline 17 & $\begin{array}{l}\text { Provide sufficient opportunities for } \\
\text { assessment. }\end{array}$ & 65,56 & 17,41 & 11,85 & 5,19 & 0,00 & 0,00 & 82,96 \\
\hline 18 & Discuss the progress of students. & 45,19 & 46,30 & 5,93 & 2,22 & 0,37 & 0,00 & 91,48 \\
\hline 19 & $\begin{array}{l}\text { Return graded assignments in a timely } \\
\text { manner. }\end{array}$ & 91,85 & 5,56 & 2,59 & 0,00 & 0,00 & 0,00 & 97,41 \\
\hline & Average & 71,93 & 20,22 & 6,30 & 1,48 & 0,07 & 0,00 & 92,15 \\
\hline
\end{tabular}

Within Dimension 5: Emphasizing Time on Tasks

\begin{tabular}{|c|l|c|c|c|c|c|c|c|}
\hline Item & \multicolumn{1}{|c|}{ Item description } & SA & A & MA & MD & D & SD & SAA \\
\hline 20 & $\begin{array}{l}\text { Start the class with a puzzle to be solved } \\
\text { or a mystery to be understood. }\end{array}$ & 38,15 & 50,00 & 8,89 & 2,96 & 0,00 & 0,00 & 88,15 \\
\hline 21 & $\begin{array}{l}\text { Estimate and communicate the amount } \\
\text { of time to be spent on tasks. }\end{array}$ & 39,63 & 48,52 & 5,19 & 3,33 & 2,59 & 0,74 & 88,15 \\
\hline 22 & $\begin{array}{l}\text { Encourage rehearsal of oral } \\
\text { presentations }\end{array}$ & 49,26 & 35,93 & 6,67 & 4,07 & 2,96 & 1,11 & 85,19 \\
\hline 23 & $\begin{array}{l}\text { Establish consequences for } \\
\text { non-completion of work }\end{array}$ & 45,56 & 43,70 & 7,78 & 2,96 & 0,00 & 0,00 & 89,26 \\
\hline \multicolumn{2}{|c|}{ Average } & 43,15 & 44,54 & 7,13 & 3,33 & 1,39 & 0,46 & 87,69 \\
\hline
\end{tabular}


Within Dimension 6 Communicating High Expectations

\begin{tabular}{|c|l|c|c|c|c|c|c|c|}
\hline Item & \multicolumn{1}{|c|}{ Item description } & SA & A & MA & MD & D & SD & SAA \\
\hline 24 & Set challenging goals for all courses. & 56,30 & 28,52 & 15,19 & 0,00 & 0,00 & 0,00 & 84,81 \\
\hline 25 & $\begin{array}{l}\text { Provide examples of excellent use of } \\
\text { English that clearly communicate future } \\
\text { English learning goals. }\end{array}$ & 85,19 & 12,96 & 1,85 & 0,00 & 0,00 & 0,00 & 98,15 \\
\hline 26 & $\begin{array}{l}\text { Motivate students to have a good } \\
\text { command of English both written and } \\
\text { orally. }\end{array}$ & 93,33 & 4,44 & 2,22 & 0,00 & 0,00 & 0,00 & 97,78 \\
\hline 27 & $\begin{array}{l}\text { Set activities that require familiarity } \\
\text { with different grammar points, } \\
\text { vocabulary words, pronunciation, and } \\
\text { cultural competencies. }\end{array}$ & 78,89 & 13,33 & 7,78 & 0,00 & 0,00 & 0,00 & 92,22 \\
\hline 28 & $\begin{array}{l}\text { Motivate the students to achieve certain } \\
\text { level of English proficiency-equivalent } \\
\text { to 550 TOEFL score. }\end{array}$ & 61,85 & 24,44 & 12,59 & 1,11 & 0,00 & 0,00 & 86,30 \\
\hline $\begin{array}{l}\text { Provide authentic use of English } \\
\text { in thected to be achieved by the students } \\
\text { newspaper or English TV news. }\end{array}$ & 73,70 & 19,63 & 3,70 & 2,96 & 0,00 & 0,00 & 93,33 \\
\hline 30 & $\begin{array}{l}\text { Bring the students to a workplace } \\
\text { environment where a high level of } \\
\text { English proficiency is required. }\end{array}$ & 38,15 & 24,81 & 25,19 & 11,85 & 0,00 & 0,00 & 62,96 \\
\hline \multicolumn{1}{|l|}{ Average } & 78,43 & 14,81 & 6,76 & 0,00 & 0,00 & 0,00 & 93,24 \\
\hline
\end{tabular}

Within Dimension 7: Respecting Diverse Talents and Ways of Learning

\begin{tabular}{|c|l|c|c|c|c|c|c|c|}
\hline Item & \multicolumn{1}{|c|}{ Item description } & SA & A & MA & MD & D & SD & SAA \\
\hline 31 & $\begin{array}{l}\text { Respect students' diverse talents and } \\
\text { ways of learning. }\end{array}$ & 42,22 & 49,26 & 8,52 & 0,00 & 0,00 & 0,00 & 91,48 \\
\hline 32 & Cater to students' learning styles. & 43,33 & 39,63 & 17,04 & 0,00 & 0,00 & 0,00 & 82,96 \\
\hline 33 & Cater to the students' needs. & 47,41 & 47,04 & 5,56 & 0,00 & 0,00 & 0,00 & 94,44 \\
\hline 34 & $\begin{array}{l}\text { Provide the students with various ways } \\
\text { to explain important concepts. }\end{array}$ & 47,04 & 40,74 & 12,22 & 0,00 & 0,00 & 0,00 & 87,78 \\
\hline \multicolumn{1}{|c|}{ Average } & 45,00 & 44,17 & 10,83 & 0,00 & 0,00 & 0,00 & 89,17 \\
\hline
\end{tabular}

\section{Copyrights}

Copyright for this article is retained by the author(s), with first publication rights granted to the journal.

This is an open-access article distributed under the terms and conditions of the Creative Commons Attribution license (http://creativecommons.org/licenses/by/4.0/). 